\title{
A clinical study on the effects of pulsatile cardiopulmonary bypass on the blood endotoxin levels
}

Levels of endogenous endotoxins have been reported to increase after cardiopulmonary bypass. Endotoxin levels have also been implicated in multiple organ failure and may contribute to the immunocompromised state seen after bypass. We evaluated the effects of pulsatile cardiopulmonary bypass circulation on endogenous endotoxin levels. The study population consisted of 15 consecutive adult patients who underwent cardiac operations with cardiopulmonary bypass. Pulsatile flow was used during aortic crossclamping in eight patients (group I) and nonpulsatile flow was used in the remaining seven patients (group II). Changes in blood endotoxin levels were monitored during aortic crossclamping, after release of the clamp, and after weaning from bypass. The blood endotoxin level at each stage was expressed as a percentage of the level at the beginning of bypass. Group I patients a significantly lower blood endotoxin percentage than group II (from 20 to 120 minutes after the initiation of aortic crossclamping). In group I, the blood endotoxin percentage was nearly constant during aortic crossclamping. After release of aortic crossclamping, group I also had a lower blood endotoxin percentage than group II. Endogenous endotoxin levels appear to increase in the presence of intestinal congestion and ischemia. Improvement in intestinal circulation by pulsatile cardiopulmonary bypass may prevent increases in endogenous endotoxin levels by reducing these factors. (J THORAC CARDIOVASC SURG 1994;108:620-5)

Shoji Watarida, MD, Atsumi Mori, MD, Masahiko Onoe, MD, Ryoko Tabata, MD,

Shoichiro Shiraishi, MD, Takaaki Sugita, MD, Takehisa Nojima, MD,

Yasuhiko Nakajima, MD, and Shuichi Matsuno, MD, Shiga, Japan

he term endotoxin was coined in 1892 by Pfeiffer after toxins found in a heat-resistant strain of cholera bacilli. In the 1950s, Westphal demonstrated that endotoxins were primarily lipopolysaccharides. Clinically, endotoxins were first measured by Levin, Tomasulo, and Oser $^{1}$ in 1968. They described a method of detecting endotoxins based on the aggregation and gel formation of minute amounts of endotoxins by Limulus lysate (a component of Limulus blood cells). Various methods have since been developed to analyze endotoxins qualitatively and quantitatively. By means of these methods, the diverse biolog-

From The Second Department of Surgery, Shiga University of Medical Science, Otsu, Japan.

Received for publication Sept. 24, 1993.

Accepted for publication March 16, 1994.

Address for reprints: Shoji Watarida, MD, The Second Department of

Surgery, Shiga University of Medical Science, Seta Tsukinowa,

- Otsu, Shiga, 520-21, Japan.

Copyright $\odot 1994$ by Mosby-Year Book, Inc.

$0022-5223 / 94 \$ 3.00+0 \quad 12 / 1 / 56706$ ic activities of endotoxins have been discovered. Numerous reports have indicated that endotoxemia is involved in postoperative multiple organ failure ${ }^{2,3}$ and that levels may increase during cardiopulmonary bypass (CPB). ${ }^{4}$ Inasmuch as immune function appears to decrease after $\mathrm{CPB},{ }^{5-7}$ we hypothesized that reduction of blood endotoxin levels may help prevent postoperative multiple organ failure and achieve better surgical results. $\mathrm{We}^{8-10}$ have previously reported clinical and experimental studies on the usefulness of pulsatile CPB. In this study, we hypothesized that pulsatile CPB might decrease endogenous endotoxemia by improving splanchnic blood flow, and we examined the association between pulsatile CPB on the blood endotoxin levels. The aim of this study was to examine the usefulness of pulsatile CPB for reducing the endogeneous endotoxin levels in the blood.

\section{Patients and methods}

Our study population consisted of 15 consecutive adult patients who underwent cardiac operations with $\mathrm{CPB}$, and informed consent was obtained from each patient. Patients were 
Table I. Demographic and operative data

\begin{tabular}{|c|c|c|c|c|c|c|c|c|}
\hline $\begin{array}{c}\text { Patient } \\
\text { No. }\end{array}$ & $\begin{array}{l}\text { Age } \\
(y r)\end{array}$ & Sex & Diagnosis & Procedure & $\begin{array}{c}\text { Total } \\
\text { CPB time } \\
\text { (min) }\end{array}$ & $\begin{array}{c}\text { Aortic crossclamp } \\
\text { time (min) }\end{array}$ & $\begin{array}{c}\text { Minimum rectal } \\
\text { temperature } \\
\left({ }^{\circ} \mathrm{C}\right) \\
\end{array}$ & Flow \\
\hline 1 & 56 & M & $\mathrm{AP}$ & $\mathrm{CABG}$ & 425 & 173 & 24.2 & P \\
\hline 2 & 52 & $\mathbf{M}$ & $\mathrm{AP}$ & $\mathrm{CABG}$ & 158 & 50 & 28.0 & $\mathbf{P}$ \\
\hline 3 & 47 & $F$ & MS & MVR & 247 & 130 & 20.7 & $\mathbf{P}$ \\
\hline 4 & 61 & F & MS & MVR & 218 & 98 & 21.9 & $\mathrm{P}$ \\
\hline 5 & 29 & $\mathbf{F}$ & inECD & Correction & 198 & 77 & 22.7 & $\mathrm{P}$ \\
\hline 6 & 56 & $\mathbf{M}$ & AP & CABG & 296 & 175 & 24.7 & $\mathrm{P}$ \\
\hline 7 & 62 & $\mathbf{F}$ & ASD,MR & ASD closure, MVR & 290 & 131 & 25.7 & $\mathrm{P}$ \\
\hline 8 & 41 & $\mathrm{~F}$ & MS & MVR & 195 & 104 & 24.7 & $\mathrm{P}$ \\
\hline 9 & 68 & M & $\mathrm{AP}$ & CABG & 298 & 155 & 24.7 & NP \\
\hline 10 & 65 & M & AP & CABG & 328 & 156 & 24.9 & NP \\
\hline 11 & 57 & M & AP & $\mathrm{CABG}$ & 278 & 108 & 25.5 & NP \\
\hline 12 & 61 & $\mathbf{M}$ & AP & CABG & 296 & 146 & 26.3 & NP \\
\hline 13 & 60 & M & $\mathrm{AP}$ & CABG & 345 & 168 & 25.8 & NP \\
\hline 14 & 63 & $F$ & MR & MVR & 194 & 95 & 23.9 & NP \\
\hline 15 & 29 & $\mathbf{F}$ & inECD & Correction & 152 & 93 & 25.5 & NP \\
\hline
\end{tabular}

$C P B$, Cardiopulmonary bypass; $A P$, angina pectoris; $M S$, mitral stenosis; inECD, incomplete endocardial cushion defect; $A S D$, atrial septal defect; $M R$, mitral regurgitation; $C A B G$, coronary artery bypass grafting; $M V R$, mitral valve replacement; $P$, pulsatile; $N P$, nonpulsatile.

enrolled between April 1988 and March 1989 (Table I). No study patient had any preoperative sign of clinical infection. The study was approved by the institutional review board and informed consent was obtained from each patient. There were eight men and seven women in the study. Patients' ages at the time of operation ranged from 29 to 68 years, with an average of $53.8 \pm 12.1$ years (mean \pm standard deviation). The preoperative diagnosis was angina pectoris in nine patients, mitral stenosis in four patients, incomplete-type endocardial cushion defect in two patients, and a combination of atrial septal defect and mitral regurgitation in one patient. The surgical procedure was coronary artery bypass grafting in nine patients, mitral valve replacement in five, and total correction in three patients, Intraoperative anesthetic management was uniform for all patients. Pulsatile and nonpulsatile CPB flow was used during aortic crossclamping. Pulsatile flow was generated with a Sarns 7400 roller pump (Sarns Inc. $3 \mathrm{M}$ Health Care, Ann Arbor, Mich.) at a pump flow rate of $2.4 \mathrm{~L} / \mathrm{min}$ per square meter body surface area, a pulse pressure of $30 \mathrm{~mm} \mathrm{Hg}$, a mean blood pressure of $50 \mathrm{~mm} \mathrm{Hg}$, and a pulse rate of 70 beats $/ \mathrm{min}$. Pulsatile flow was used only during aortic crossclamping. Nonpulsatile flow was generated with a Sarns 7400 roller pump at a flow rate of $2.4 \mathrm{~L} / \mathrm{min}$ per square meter body surface area and a mean blood pressure of $50 \mathrm{~mm} \mathrm{Hg}$. Oxygenation was provided by a membrane oxygenator in all cases (Capiox E, Terumo Corp., Tokyo, Japan). A cold blood cardioplegic solution was administered intermittently via the aortic root and ice cold Ringer's solution was applied topically to the heart. The patients were divided into two groups on the basis of the use of pulsatile or nonpulsatile flow during CPB: the pulsatile flow group consisted of eight patients (group I) and the nonpulsatile flow group consisted of seven patients (group II). Blood endotoxin levels during aortic crossclamping, during rewarming after unclamping, and after weaning from the artificial heart-lung system were measured and expressed as a percentage of the level at the beginning of CPB (Et\%).

Blood sampling for endotoxins. All blood sampling was performed in an aseptic fashion and endotoxin-free collection tubes were used. During CPB with the artificial heart-lung sys-
Table II. Patient data

\begin{tabular}{lcc}
\hline & $\begin{array}{c}\text { Group I } \\
(\mathrm{n}=8)\end{array}$ & \multicolumn{1}{c}{$\begin{array}{c}\text { Group II } \\
(\mathrm{n}=7)\end{array}$} \\
\hline Age (yr) & $50.5 \pm 11.1$ & $57.5 \pm 13.0$ \\
$\begin{array}{c}\text { Total CPB time } \\
\text { (min) }\end{array}$ & $253.3 \pm 84.0$ & $270.1 \pm 70.9$ \\
$\begin{array}{c}\text { Aortic crossclamp } \\
\text { time (min) } \\
\begin{array}{c}\text { Minimum rectal } \\
\text { temperature }\left({ }^{\circ} \mathrm{C}\right)\end{array}\end{array}$ & $117.3 \pm 43.9$ & $131.6 \pm 31.8$ \\
\hline
\end{tabular}

Values are expressed as mean \pm standard deviation of the mean. There were no significant differences between the groups for these parameters

tem, the blood was sampled from the venous route of the system. After the patient was weaned from CPB, the blood was sampled from the pulmonary artery with a Swan-Ganz catheter (Baxter Healthcare Corp., Edwards Div., Irvine, Calif.). Blood sampling was performed during the following intervals: (1) at the beginning of CPB, (2) every 20 minutes after initiation of aortic crossclamping, (3) every 30 minutes after release of the aortic crossclamp, (4) immediately after weaning from CPB, (5) 2 hours after weaning from CPB, and (6) 12 hours after weaning from CPB.

Measurement of endotoxins. Endotoxin levels were measured with an endotoxin-specific chromogenic test (Endospecy test; Seikagaku Kogyo, Tokyo, Japan). This test consists of factor G-free Limulus amebocyte lysate and a chromogenic substrate. ${ }^{9}$ The sample was pretreated with perchloric acid and sodium hydroxide before endotoxin levels were determined. The endotoxin level at the beginning of CPB was designated as $100 \%$ (baseline level). Endotoxin levels on subsequent occasions were expressed as a percentage relative to the baseline level (Et\%) after correction for hematocrit levels. This allowed for comparisons of endotoxin levels at a hematocrit value of $25 \%$.

Statistical analysis. Values were expressed as mean \pm standard deviation. The significance of differences was tested by 
Table III. Changes in endotoxin levels during aortic crossclamping

\begin{tabular}{|c|c|c|c|c|c|c|}
\hline \multirow{2}{*}{$\begin{array}{c}\text { Before } \\
\text { clamping }\end{array}$} & \multicolumn{6}{|c|}{ Time after start of aortic crossclamping } \\
\hline & $20 \mathrm{~min}$ & $40 \mathrm{~min}$ & $60 \mathrm{~min}$ & $80 \mathrm{~min}$ & $100 \mathrm{~min}$ & $120 \mathrm{~min}$ \\
\hline \multicolumn{7}{|l|}{ Group I } \\
\hline Range & $24 \%-150 \%$ & $37 \%-123 \%$ & $26 \%-104 \%$ & $56 \%-100 \%$ & $86 \%-105 \%$ & $47 \%-178 \%$ \\
\hline $\begin{array}{l}100 \% \\
(n=8)\end{array}$ & $\begin{array}{c}83 \% \pm 39 \% \\
(n=8)\end{array}$ & $\begin{array}{c}93 \% \pm 33 \% \\
(n=8)\end{array}$ & $\begin{array}{c}69 \% \pm 33 \% \\
(n=7)\end{array}$ & $\begin{array}{c}87 \% \pm 18 \% \\
(n=6)\end{array}$ & $\begin{array}{c}97 \% \pm 8 \% \\
(n=5)\end{array}$ & $\begin{array}{c}93 \% \pm 61 \% \\
(n=4)\end{array}$ \\
\hline \multicolumn{7}{|l|}{ Group II } \\
\hline Range & $65 \%-294 \%$ & $100 \%-325 \%$ & $38 \%-282 \%$ & $137 \%-260 \%$ & $130 \%-480 \%$ & $117 \%-480 \%$ \\
\hline $\begin{array}{l}100 \% \\
(n=7)\end{array}$ & $\begin{array}{c}172 \% \pm 84 \% * \\
(n=7)\end{array}$ & $\begin{array}{c}183 \% \pm 98 \% * \\
(n=7)\end{array}$ & $\begin{array}{c}152 \% \pm 93 \% * \\
(n=7)\end{array}$ & $\begin{array}{c}185 \% \pm 53 \% * \\
(n=7)\end{array}$ & $\begin{array}{c}251 \% \pm 146 \% * \\
\quad(n=5)\end{array}$ & $\begin{array}{c}245 \% \pm 100 \% * \\
(n=4)\end{array}$ \\
\hline
\end{tabular}

Values are expressed as mean \pm standard deviation of the mean.

${ }^{*} p<0.05$ when compared with group I.

Table IV. Changes in endotoxin levels after release of aortic crossclamp

\begin{tabular}{cccccc}
\hline $\begin{array}{c}\text { Before } \\
\text { clamping }\end{array}$ & $\begin{array}{c}30 \text { min after } \\
\text { release of } A C C\end{array}$ & $\begin{array}{c}60 \text { min after } \\
\text { release of } A C C\end{array}$ & $\begin{array}{c}\text { Immediately } \\
\text { after CPB }\end{array}$ & $\begin{array}{c}2 \mathrm{hr} \\
\text { after CPB }\end{array}$ & $\begin{array}{c}12 \mathrm{hr} \\
\text { after CPB }\end{array}$ \\
\hline Group I & & & & & \\
Range & $50 \%-150 \%$ & $16 \%-354 \%$ & $32 \%-107 \%$ & $41 \%-234 \%$ & $33 \%-295 \%$ \\
$100 \%$ & $88 \% \pm 33 \%$ & $74 \% \pm 45 \%$ & $57 \% \pm 24 \%$ & $102 \% \pm 62 \%$ & $172 \% \pm 106 \%$ \\
$(n=8)$ & $(n=8)$ & $(n=8)$ & $(n=8)$ & $(n=8)$ & $(n=8)$ \\
Group II & & & & $35 \%-424 \%$ & $63 \%-1283 \%$ \\
Range & $68 \%-233 \%$ & $65 \%-250 \%$ & $54 \%-336 \%$ & $175 \% \pm 158 \% *$ & $362 \% \pm 215 \%$ \\
$100 \%$ & $171 \% \pm 61 \% *$ & $143 \% \pm 68 \% *$ & $143 \% \pm 116 \% *$ & $(n=7)$ & $(n=7)$ \\
$(n=7)$ & $(n=7)$ & $(n=7)$ & $(n=7)$ & 7
\end{tabular}

Values are expressed as mean \pm standard deviation of the mean. $A C C$, Aortic crossclamp; $C P B$, cardiopulmonary bypass.

${ }^{*} p<0.05$ when compared with group I.

means of a Mann-Whitney $U$ test. Differences were considered to be significant at a $p$ value of less than 0.05 . Statview II (Abacus Concepts, Inc.) statistical software for the Macintosh computer was used for statistical analyses.

\section{Results}

The total CPB time did not differ significantly between group I ( 158 to 425 minutes, $253.3 \pm 84.0$ minutes) and group II (152 to 345 minutes, $270.1 \pm 70.9$ minutes). Aortic crossclamping time also did not differ significantly between group I ( 50 to 175 minutes, $117.3 \pm 43.9$ minutes) and group II ( 93 to 168 minutes, $131.6 \pm 31.8$ minutes). Finally, the minimum rectal temperature also did not differ significantly between group I $\left(21.9^{\circ}\right.$ to $\left.28.0^{\circ} \mathrm{C}, 24.1^{\circ} \pm 2.3^{\circ} \mathrm{C}\right)$ and group II $\left(23.9^{\circ}\right.$ to $26.3^{\circ}$ C, $25.2^{\circ} \pm 0.3^{\circ} \mathrm{C}$ ) (Table II). One patient with mitral stenosis (case 4, group I) died on postoperative day 16 after mitral valve replacement because of multiple organ failure caused by a low cardiac output syndrome. The other 14 patients had no significant postoperative complications. Endotoxins were not found in any of the priming fluids $(0 \mathrm{pg} / \mathrm{ml})$. Additionally, after the priming fluid was mixed in the extracorporeal circuit and circulated for
10 minutes, endotoxins were still not found in any of our patients $(0 \mathrm{pg} / \mathrm{ml})$. No great variation was observed among the patients. The hematocrit value during CPB was $23 \%$ to $28 \%$. No patients required any blood transfusions.

Changes in Et \% during aortic crossclamping (Table III, Fig. 1). Twenty minutes after the initiation of aortic crossclamping, the Et $\%$ in group I $(83 \% \pm 39 \%)$ was significantly lower than in group II $(172 \% \pm 84 \%)$ $(p<0.05)$. This parameter then remained significantly higher in group II than in group I until 120 minutes after the initiation of aortic crossclamping $(p<0.05)$. In group $\mathrm{II}$, the $\mathrm{Et} \%$ increased slightly during the course of aortic crossclamping. In group I, however, the Et\% did not change during the course of aortic crossclamping.

Changes in Et \% after release of aorticcross clamp (Table IV, Fig. 2). At two points during the rewarming processes (30 and 60 minutes after release of the aortic clamp), the Et\% was significantly lower in group I ( $88 \pm 33 \%$ at 30 minutes and $74 \% \pm 45 \%$ at 60 minutes) $(p<0.05)$ than in group II $(171 \% \pm 61 \%$ at 30 minutes and $143 \% \pm 68 \%$ at 60 minutes). In group II, the Et $\%$ at 60 minutes after release of the aortic crossclamp (that is, 


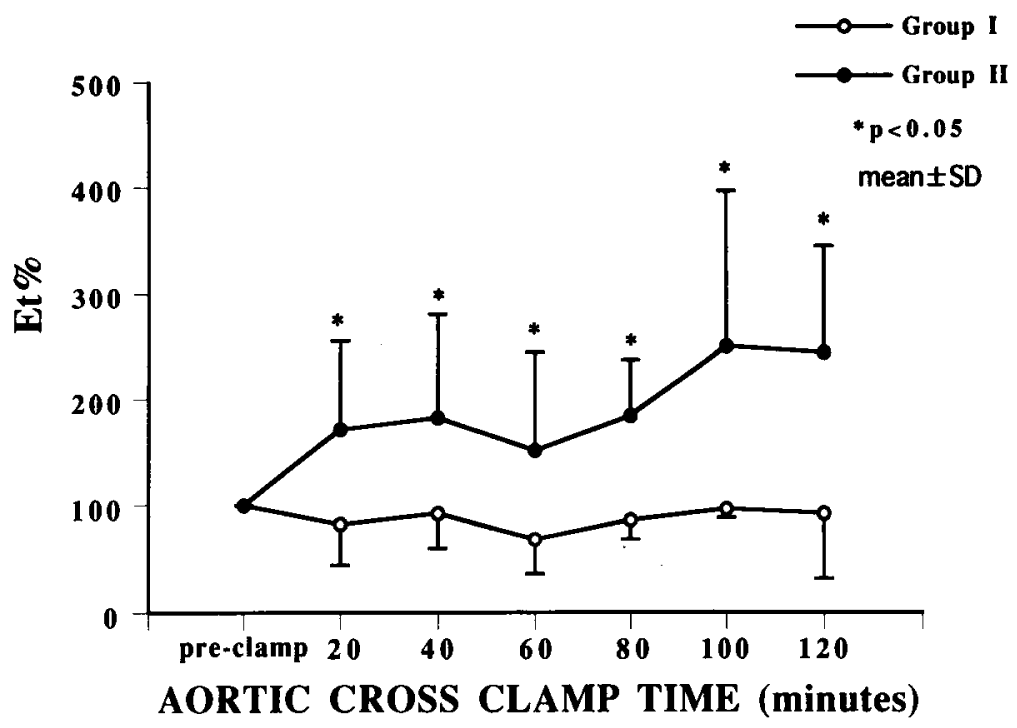

Fig. 1. Changes in Et\% during aortic crossclamping in the two groups. $S D$, Standard deviation. ${ }^{*} p<0.05$ when compared with group I.

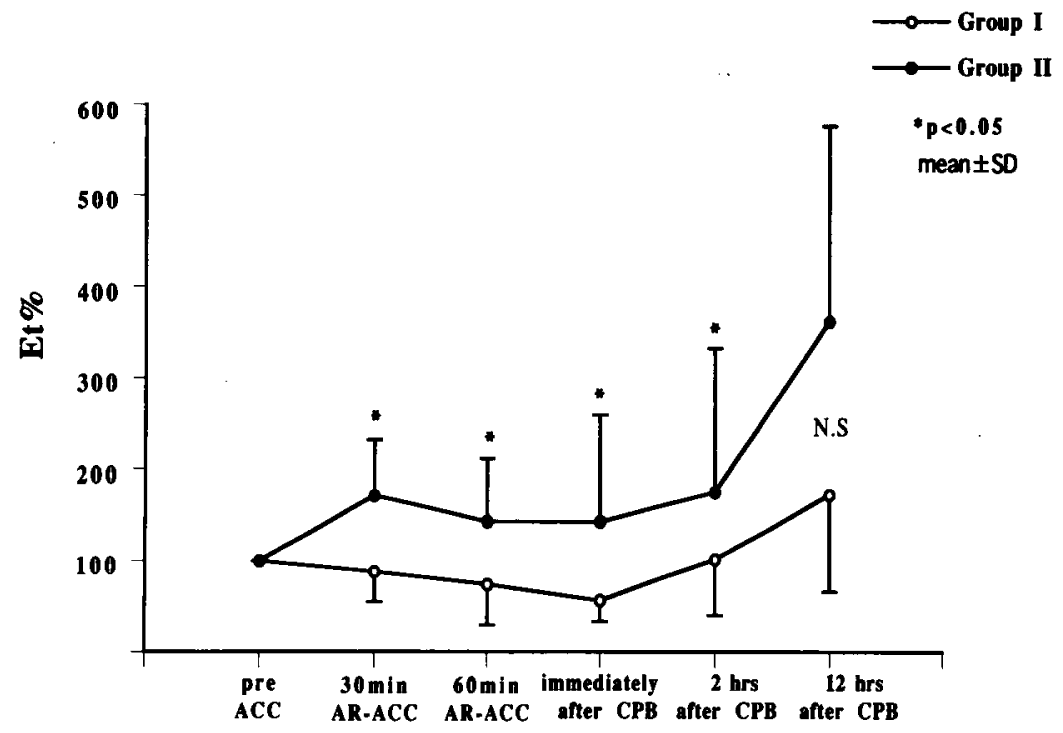

Fig. 2. Changes in Et\% after release of aortic crossclamp in the two groups. ${ }^{*} p<0.05$ when compared with group I. $A R-A C C$, After release of aortic crossclamp; $S D$, standard deviation.

the point when rewarming was nearly complete) was lower than the $\mathrm{Et} \%$ recorded 30 minutes after release of the aortic crossclamp. This difference, however, was not statistically significant.

Changes in $\mathrm{Et} \%$ after weaning from CPB (Table IV. Fig. 2). The $E t \%$ was significantly higher in group II than in group I immediately and 2 hours after weaning from CPB (group I. $57 \% \pm 24 \%$ and $102 \% \pm 62 \%$; group II, $143 \% \pm 116 \%$ and $175 \% \pm 158 \%$, respectively). The
Et\% remained higher in group II $(362 \% \pm 215 \%)$ than in group I $(172 \% \pm 106 \%)$ even 12 hours after cessation of CPB.

\section{Discussion}

Endotoxins, that is, lipopolysaccharides, constitute the adventitia of the cell wall of gram-negative bacilli and have diverse biologic activities and may contributute to the development of multiple organ failure. ${ }^{12,13}$ Elevated 
blood levels of endotoxins (i.e., endotoxemia) have been noted in patients with multiple organ failure. An impairment of reticuloendothelial or immune function may lead to endogenous endotoxemia by intestinal gram-negative bacilli, such as Escherichia coli. It has been noted that immune function appears to be depressed in patients immediately after $\mathrm{CPB}^{5-7}$ and that the risk for multiple organ failure caused by endogeneous endotoxemia is high during this period. Only a few reports examining endotoxin levels during CPB have been published, and no reports assessing endotoxin levels during pulsatile CPB have appeared. Rocke and associates ${ }^{4}$ have reported that blood endotoxin levels increase during aortic crossclamping. Jansen and colleagues ${ }^{14}$ have reported that the release of endotoxin, associated with the formation of tumor necrosis factor, plays an additional role in the development of the whole-body inflammatory reaction, independent of the material activation. Andersen and colleagues ${ }^{15}$ have also reported that patients "free of endotoxins" before the operation had rising concentrations to $64 \mathrm{ng} / \mathrm{L}$ by the end of CPB, with a peak median level of $95 \mathrm{ng} / \mathrm{L}$ at 90 minutes after CPB. Nilsson and coworkers have reported that endotoxin levels increase during CPB. They suggested that this endotoxin release may be from the extracorporeal equipment. In our study, however, endotoxins were not found in any of the priming fluids. The increase in endotoxin after release of the aortic crossclamp might be explained by the preceding hypoperfusion of the splanchnic bed by reduced peak arterial pressure associated with the nonpulsatile flow of the pump during CPB. ${ }^{4}$ In the present study, patients in the nonpulsatile $\mathrm{CPB}$ group had a significant increase in blood endotoxin levels with aortic crossclamping. In the pulsatile CPB group, however, no significant elevation was noted in endogenous endotoxin levels during aortic crossclamping. Thus our study demonstrates the clinical utility of pulsatile CPB in preventing increases in endogenous endotoxin levels.

Totsuka and associates, ${ }^{3,17}$ have reported three possible routes for the transfer of endogenous endotoxins into the blood: (1) transfer from the intestine into the portal vein; (2) transfer from the intestine into the systemic circulation via the intestinal lymphatics, thoracic duct, and venous angle; and (3) adsorption into the portal vein and intestinal lymphatics from the peritoneal cavity. An important relationship was noted between the lymphatic system and the intestine in endogenous endotoxemia. This relationship is based on observations that demonstrate that thoracic duct drainage significantly reduces blood endotoxin levels. Previous studies have shown that CPB can lead to ischemic damage of organs perfused by the splanchnic circulation. ${ }^{18,19}$ During CPB, the intestine tends to become edematous and congested because of perfusion of blood with low osmotic pressure. Thus endogenous endotoxin levels in intestinal blood are likely to increase during CPB. The liver also tends to become congested during $\mathrm{CPB}$, and Kupffer cell function is believed to be disturbed during this period, ${ }^{20}$ leading to further elevations in hepatic blood endotoxin levels. A possible mechanism to explain the decrease in endotoxin levels noted with pulsatile CPB is that pulsatile CPB increases intestinal ${ }^{21}$ and hepatic blood flow ${ }^{22}$ and improves splanchnic circulation, thereby leading to a decrease in the transfer of endogenous endotoxins into the blood and an improvement in the endotoxin-disposing capability of the liver. Fortunately, in our study, endotoxin-induced multiple organ failure was not recognized. However, we consider that pulsatile CPB should be used during aortic crossclamping in cardiac operations for patients whose status is poor before the operation.

\section{REFERENCES}

1. Levin J, Tomasulo PA, Oser RS. Detection of endotoxin in human blood and demonstration of an inhibitor. J Lab Clin Med 1970;75:903-11.

2. Shimada H, Matsuba A, Nimoto S, Hujita $H$, Nakagawa G, Tsuchiya S. Liver failure after hepatic resection. J Jpn Surg Soc 1989;90:566-72.

3. Totsuka M, Sasaki K, Kobayashi K, et al. Development of MOF as result of DIC: clinical and experimental studies. J Jpn Surg Soc 1982;84:865-8.

4. Rocke DA, Graffin SL, Wells MT, Koen Y, Brock-Utine JG. Endotoxemia associated with cardiopulmonary bypass. J Thorac Cardiovasc Surg 1987;93:832-7.

5. Irbarren CS, Ekestrom S. The causes of death after openheart surgery. J THORAC CARDIOVASC SURG 1964;47:72539.

6. Kirklin JK, Westaby S, Blackstone EH, Chenoweth DE, Pacifico AD. Complement and the damaging effects of cardiopulmonary bypass. J THORAC CARDiovasC SURG 1983;86:845-57.

7. Jones HM, Matthews N, Vaughan RS, Stark JM. Cardiopulmonary bypass and complement activation: involvement of classical and alternative pathways. Anaesthesia 1982;37:629-33.

8. Mori A, Tabata R, Nakamura Y, Watanabe K, Onoe M, Okada Y. Effects of pulsatile cardiopulmonary bypass on carbohydrate and lipid metabolism. J Cardiovasc Surg 1988;28:621-6.

9. Watanabe K, Mori A, Onoe M, Okada Y. The effects of pulsatile cardiopulmonary bypass on regional blood flow under profound hypothermia: liver, pancreas, renal cortex and medulla. J Shiga Univ Med Sci 1987;2:63-75.

10. Onoe M. Regional blood flow and metabolism in brain during pulsatile and non-pulsatile perfusion under profound hypothermia with total circulatory arrest. J Shiga Univ Med Sci 1989;4:121-33. 
11. Obayashi T, Tamura H, Tanaka S, Ohki M, Takahashi S, Kawai T. Endotoxin-inactivating activity in normal and pathological human blood samples. Am Soc Microbiol 1986;53:294-7.

12. Trann DD, Cuesta MA, van Leeuwen PA, Nauta JJ, Wesdorp RI. Risk factor for multiple organ system failure and death in critically injured patients. Surgery 1993; 114 : 21-30.

13. Ghosh S, Latimer RD, Gray BM, Harwood RJ, Oduro A. Endotoxin-induced organ injury. Crit Care Med. 1993;21 (2 Suppl):S19-24.

14. Jansen NJG, Oeveren W, Gu YJ, Vliet MH, Eijsman L, Wildevuur CRH. Endotoxin release and tumor necrosis factor formation during cardiopulmonary bypass. Ann Thorac Surg 1992;54:744-8.

15. Andersen LW, Baek L, Degn H, Lehd J, Krasnik M, Rasmussen JP. Presence of circulating endotoxins during cardiac operations. J THORAC Cardiovasc SuRG 1987; 93: 115-9.

16. Nilsson L, Kulander L, Nystrom SO, Eriksson O. Endotoxins in cardiopulmonary bypass. $\mathrm{J}$ THORAC CARDIOVASC SURG 1990;100:777-80.
17. Totsuka M. MOF and endotoxin. SaishinIgaku 1984; 39: 2490-6.

18. Horton EH, Murthy SK, Seal RME. Haemorrhagic necrosis of small intestine: acute pancreatitis following open heart surgery. Thorax 1968;23:438-48.

19. Feiner H. Pancreatitis after cardiac surgery: a morphologic study. Am J Surg 1976;131:684-8.

20. Subramanian V, McLeod J, Grans H. Effect of extracorporeal circulation on reticuloendothelial function. I. Experimental evidence for impaired reticuloendothelial function following cardiopulmonary bypass in rats. Surgery 1968; 64:775-84.

21. Ohri SK, Desai JB, Gaer JA, et al. Intraabdominal complications after cardiopulmonary bypass. Ann Thorac Surg 1991;52:826-31.

22. Mori A, Watanabe K, Onoe M, et al. Regional blood flow in the liver, pancreas and kidney during pulsatile and nonpulsatile perfusion under profound hypothermia. Jpn Circ J 1988;52:219-27.

\section{Availability of JouRNAL back issues}

As a service to our subscribers, copies of back issues of THE Journal of THORACIC AND CARDiovascular SuRGERY for the preceding 5 years are maintained and are available for purchase from the publisher, Mosby-Year Book, Inc., at a cost of $\$ 10.50$ per issue. The following quantity discounts are available: $25 \%$ off on quantities of 12 to 23 , and one third off on quantities of 24 or more. Please write to Mosby-Year Book, Inc., Subscription Services, 11830 Westline Industrial Drive, St. Louis MO 631463318 , or call (800)453-4351 or (314)453-4351 for information on availability of particular issues. If unavailable from the publisher, photocopies of complete issues are available from University Microfilms International, 300 N. Zeeb Rd., Ann Arbor, MI 48106, (313)761-4700. 